6. Tesakova E.M., Atrops F., Meléndez G. Ostracods of the Callovian-Oxfordian boundary from Central Russia and Southern France: Similarities and differences // European Ostracodologists' Meeting VI (EOM VI) et 19 Intern. Senckenberg Conf. (5-7 Sept. 2007). Frankfurt/Main, 2007. P. 14.

7. Kiselev D., Rogov M., Guzhikov A. at al. Dubki (Saratov region, Russia), the reference section for the Callovian/Oxfordian boundary // Volumina Jurassica. 2006. V. IV. P. 177-179.

8. Матвеев А.В. Известковый нанопланктон келловея - оксфорда разреза Дубки (Саратовское Поволжье) // Юрская система России: проблемы стратиграфии и палеогеографии: Второе Всерос. совещание: науч. материалы / Отв. ред. В.А. Захаров. Ярославль, 2007. С. 160.

9. Tesakova E. Late Callovian and Early Oxfordian ostracods from the Dubki section (Saratov area, Russia): implications for stratigraphy, paleoecology, eustatic cycles and palaeobiogeography // Neues Jahrbuch fuer Geologie und Palaeontologie, Abhandlungen. 2008. № 249(1). P. 25-45.

10. Kiselev D., Rogov M., Guzhikov A. at al. Reference sections for the Callovian/Oxfordian boundary on European Russia and Northern Caucasus // Volumina Jurassica. 2009 (in press).

11. Михайлов А.М., Пименов М.В. Палеогеографическое и стратиграфическое значение петромагнитных данных по верхнему келловею-нижнему оксфорду разреза Дубки (Саратовский район) // Геологи XXI века: Материалы VIII Всерос. науч. конф. студентов, аспирантов и молодых специалистов (Саратов, 28-30 марта, 2007 г.). Саратов, 2007. C. $99-100$.

12. Сельцер В.Б. Новое местонахождение келловейнижнеоксфордской аммонитовой фауны на территории Саратовского Поволжья // Проблемы геоэкологии Саратова и области. Саратов, 1999. Вып. 3. С. 102-107.

13. Барабошкин Е.Ю., Архангельский М.С., Гужиков А.Ю. $u$ др. О строении волжского яруса в окрестностях г. Саратова // Тр. / НИИГеологии СГУ. Нов. Сер. 2001. Т. VIII. C. $62-68$.

14. Митта B.B. О пограничных отложениях келловея и оксфорда бассейна Волги // VM-Novitates. 2003. № $11.21 \mathrm{c}$. 15. Keupp H., Mitta V.V. Septenbildung bei Quenstedtoceras (Ammonoidea) von Saratov (Russland) unter anomalen
Kammerdruckbedingungen // Mitt. Geol.-Paläont. Inst. Univ. 2004. H. 88. S. 51-62.

16. Рогов М.А., Егоров Е.Ю. Полиморфизм у некоторых раннеоксфордских оппелиид (Ammonoidea) Русской платформы // Современные вопросы геологии: Материалы конф. М., 2003. С. 245-248.

17. Рогов M.A. Средне- и позднекелловейские аптихи (Ammonoidea) Русской плиты // Палеонт. журн. 2004. № 1. C. 26-33.

18. Kiselev D.N., Rogov M.A. Preliminary report on the Callovian/Oxfordian boundary in the Central Russia // 32nd Intern. Geol. Congr., electronic version posted on-line on July 20, 2004, Abs. Vol., pt. 1, abs. 177-19, P. 824.

19. Tesakova E. Late Callovian and Early Oxfordian ostracods from the Dubki section (Saratov area, Russia): implications for stratigraphy, paleoecology, eustatic cycles and palaeobiogeography // N. Jb. Geol. Paläont. Abh. 2008. V. 249, № 1. P. 25-45.

20. Захаров B.A. Бухииды и биостратиграфия бореальной верхней юры и неокома // Тр. / ИГиГ СО АН СССР. 1981. Вып. 458. 271 с.

21. Гужиков А.Ю., Молостовский Э.А. Стратиграфическая информативность численных магнитных характеристик осадочных пород (методические аспекты) // Бюл. МОИП., Отд-ние геол. 1995. Т. 70, вып. 1. С. 32-41.

22. Молостовский Э.А., Храмов А.Н. Магнитостратиграфия и ее значение в геологии. Саратов, 1997. $180 \mathrm{c}$.

23. Гужиков А.Ю. Палеомагнитная шкала и петромагнетизм юры - мела Русской плиты и сопредельных территорий (значение для общей шкалы и бореально-тетических корреляций): Автореф. дис. ... д-ра геол.-минерал. наук. Новосибирск, 2004. 32 с.

24. Norris M.S., Hallam A. Facies variations across the Middle-Upper Jurassic boundary in Western Europe and the relationship to sea-level changes // Palaeogeogr. Palaeoclimatol. Palaeoecol. 1995. V. 116. P. 189-245.

25. Dromart G., Garcia J.P., Picard S., Atrops F., Lécuyer C., Sheppard S.M.F. Ice Age at the Middle-Late Jurassic Transition? // Earth and Planetary Science Letters. 2003. V. 213. P. 205-220.

УДК 551.735 .15 (470.4)

\title{
МЕСТНЫЕ СТРАТИГРАФИЧЕСКИЕ ПОДРАЗДЕЛЕНИЯ МОСКОВСКОГО ЯРУСА СРЕДНЕГО КАРБОНА ВОЛГОГРАДСКО-САРАТОВСКОГО ПОВОЛЖЬЯ
}

\section{В.Ф. Салтыков}

Саратовский государственный университет, лаборатория петрофизики

E-mail: dekanat@geol.sgu.ru

Анализ опубликованных фактических материалов, полученных на площади Нижнего Поволжья, позволил выделить и описать восемь местных стратиграфических подразделений в московском ярусе среднего карбона. Даны литологические и палеонтологические характеристики свит и подсвит с указанием стратоти- пических разрезов в конкретных скважинах. Приводится сопоставление местных стратиграфических подразделений Нижнего Поволжья со стратотипами Подмосковья.

Ключевые слова: средний карбон, московский ярус, Нижнее Поволжье, стратиграфия, местные стратиграфические подразделения. 
Local Stratigraphic Units of the Middle Carboniferous Moscovian Stage from the Volgograd-Saratov Volga Region

\section{V.F. Saltykov}

Analysis of the published factual materials from the Lower Volga region has made it possible to distinguish and to describe eight local stratigraphic units of the Middle Carboniferous Moscovian stage. Lithologic and paleontologic characteristics of the suites and the subsuites are presented alongside with indications of the stratotype sections in particular wells. In the summary, the local stratigraphic units from the Lower Volga Region are compared with the stratotypes from the Moscow Region.

Key words: middle Carboniferous, Moskovian stage, Lower Volga region, Stratigraphy, local stratigraphical subdivisions.

\section{Введение}

Московский ярус выделен в стратотипической местности - в Подмосковье, где он разделялся по биостратиграфическим данным на четыре горизонта (ныне им придают статус подъярусов) верейский, каширский, подольский и мячковский. Такое расчленение зафиксировано в современной общей стратиграфической схеме России [1], а также в ряде сводок по стратиграфии карбона [2-4]. При этом главную роль в биостратиграфии играли фораминиферовые комплексы, в меньшей мере - брахиоподы [5], конодонты [6] и мшанки [7]. В 1990 гг. начались активные исследования, ориентированные на разработку системы местных стратонов и их увязку с общими и региональными подразделениями. Наиболее значительные результаты были получены в Подмосковье, где комплексно проанализированы материалы по лито-, био- и циклостратиграфии карбона [8].

В Поволжье подобный системный подход к исследованиям начался только в последние годы $[9,10]$. Между тем разрезы в этом районе изучались многие десятилетия. С.В. Семихатова [11] даже выделяла свиты, которые впоследствии оказались невостребованными. Деление московского яруса производилось на горизонты по аналогии с Подмосковьем [2, 4, 12-14]. Имеющиеся фактические материалы позволяют подойти к выделению местных стратонов с указанием стратотипических разрезов по скважинам с учетом новых данных, хотя биостратиграфические сведения в ряде случаев не являются полными и разнообразными - отсутствуют данные по аммонитам и конодонтам.

Московские отложения распространены на всей территории Волгоградско-Саратовского Поволжья и погребены на значительные глубины, но в отдельных местах - на западе Жирновско-Иловлинского вала и в пределах Арчединских поднятий - они выходят на современную поверхность. В статье предпринята попытка обобщения опубликованных литологических и палеонтологических данных с целью обоснования местных подразделений. В соответствии с положениями «Стратиграфического кодекса»
[15] они выделяются на основе комплекса признаков - литологической и палеонтологической характеристик, имеющих равноценное значение, фациальной принадлежности, мощности и амплитуды их колебаний по площади, соотношения с подстилающими и покрывающими отложениями с подробным описанием контактовой зоны между ними, корреляция с известными горизонтами. Учитывается географическое размещение стратонов. Расположение основных разведочных площадей, на которых изучены московские отложения, показано на рис. 1.

Верейский горизонт $\boldsymbol{C}_{2}$ vr. B общей стратиграфической шкале он соответствует фораминиферовой зоне Aljutovella aljutovica-Schubertella pauciseptata [1], но в Подмосковье выделяют две зоны - нижнюю Al. aljutovica и верхнюю Ovatella arta [8].

В Поволжье верейский горизонт представлен главным образом терригенными породами с прослоями известняков. Такой состав распространен повсеместно. Их мощность варьирует в широких пределах: на площади Приволжской моноклинали они достигают 250 м, на юге Доно-Медведицких дислокаций - 170 м, на севере - 125 м, на западе региона они убывают до 25 м. А.С. Мельникова с соавторами [2] отмечали фациальную изменчивость горизонта и невыдержанность прослоев отдельных пород по простиранию. В связи с этим данные авторы считали невозможным выделение литологических пачек на территории Волгоградской области, указывая на увеличение песчаной составляющей в пределах Доно-Медведицких дислокаций. В сводке [4] показано возрастание количества прослоев известняков с юга на север.

При выделении местного стратона на Правобережье Д.А. Кухтинов с соавторами [10] проанализировали большой фактический материал и предложили верейские образования обособлять в бахметьевскую свиту $\mathrm{C}_{2}$ bh по одноименной структуре на севере Доно-Медведицких дислокаций, где она вскрыта многими скважинами. Указанное подразделение залегает на тепловской свите $\mathrm{C}_{2}$ tp мелекесского горизонта терригенного состава, выделенной в разрезах Саратовского Правобережья (Тепловская площадь). Нижняя граница бахметьевской свиты проводится по подошве выдержанного на площади реперного (RpD) слоя известняка с верейскими фузулинидами, лежащего на глинах с тепловской микрофауной. На каротажных диаграммах она четко выделяется пиками на кривых. Эти данные и резкая смена состава фораминифер позволяют предполагать перерыв в осадконакоплении, хотя чаще в литературе указывается на согласное залегание.

В составе бахметьевской свиты Д.А. Кухтинов с коллегами различают три литологические пачки с нечетко выраженными границами. Нижняя глинистая пачка мощностью 30-40 м сложена глинами и алевролитами с редкими и тонкими прослоями песчаников с обугленными раститель- 


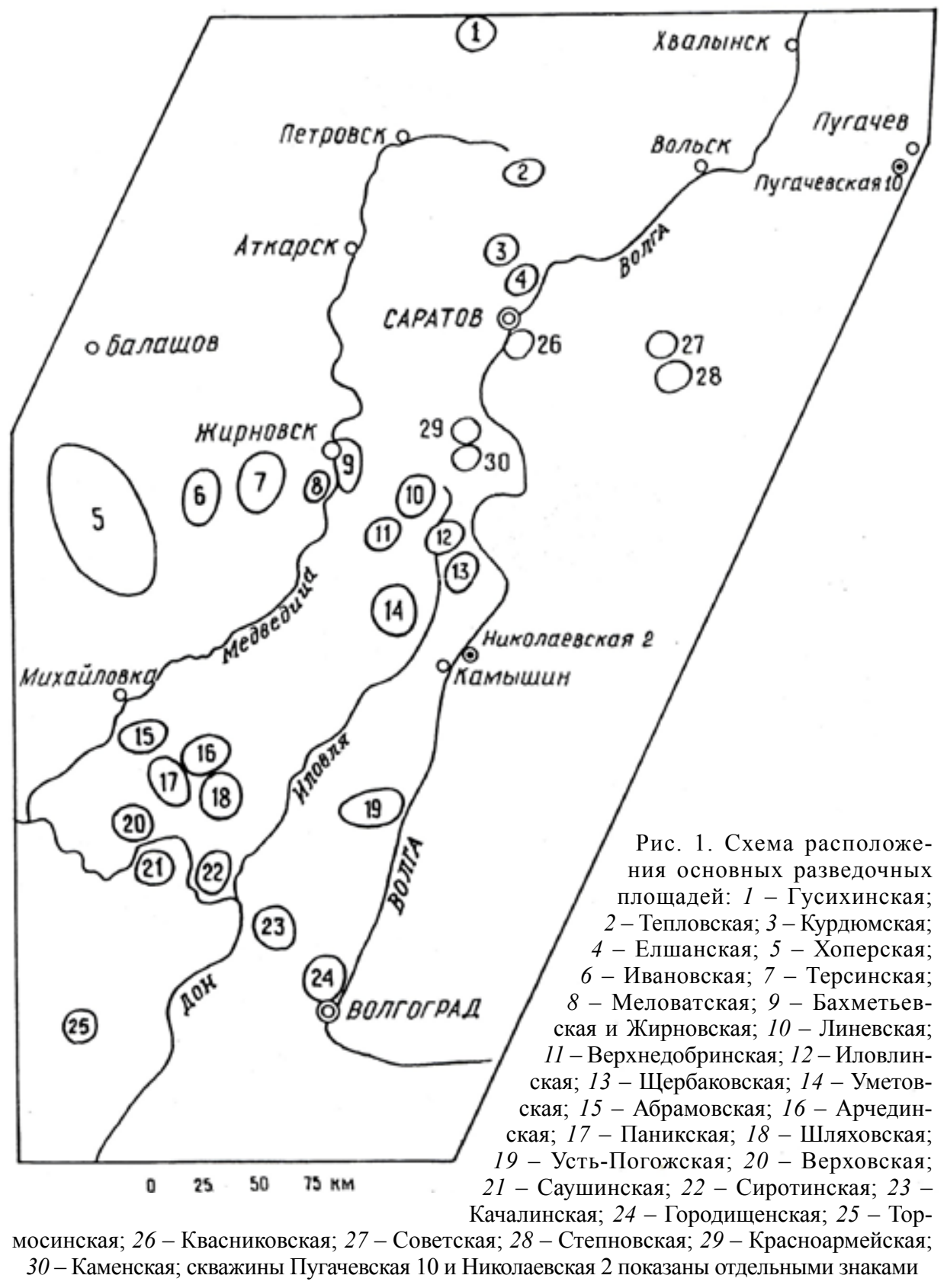

ными остатками. В ней обнаружены брахиоподы Choristites priscus (Eichw.), Ch. priscus var. senilis A. et Iv., пелециподы Carbonicola angulata Rich., Anthracomya sagitata Tschern., Najadites cf. caronata Sow. и обильные фораминиферы - Novella evoluta var. mosquensis Raus., Brunsiella ammodiscoides (Raus.), B. irregularis (Brazh. et Pot.), B. cf. densa Reitl., Eofusulina triangula (Raus. et Bel.), Schubertella ex gr. gracilis Raus.

Средняя песчано-глинистая пачка мощностью 30-70 м сложена глинами, алевролитами с прослоями песчаников, количество и мощность которых возрастает в разрезах на границе Волгоградской и Саратовской областей, где они составляют более половины мощности пачки. В редких прослоях глинистых известняков обнаружены фораминиферы Hemifusulina? concepta Chern., Aljutovella aljutovica Raus., Al. ex gr. cybea Leon., Profusulinella integra Chern., Pr. rhomboides Lee et Chen., Pseudostaffella gorskyi (Dutk.), Ps. pseudoquadrata Man., Ozawainella pararhomboidalis Man., Eofusulina trianguliformis Put. Более редко встречаются брахиоподы Phricodothyris cf. asiatica (Chao), Choristites sp., Chonetes sp. Изучая разрез по скв. 8к Тепловской площади, Е.И. Чернова [13] дополнительно описала фораминиферы Hemifusulina aff. bocki (Moell.), Pseudofusulina antiqua (Dutk.), Ps. ex gr. confusa Lee et Chen., отобранные из верхней части разреза. 
Верхняя карбонатно-терригенная пачка переменной мощности представлена чередованием глин, алевролитов, песчаников и известняков. В глинах много обугленного растительного детрита. Слои песчаников часто выклиниваются по простиранию и замещаются алевролитами. Известняки водорослевые, глинистые, участками доломитизированные. Подтверждением верейского возраста могут служить находки фораминифер Profusulinella rhomboides Lee et Chen., Pr. ex gr. pseudorhomboides Put., Pr. ovata Raus., Pseudostaffella irinovkensis Le-on., Ps. cf. gorskyi Dutk., Ps. subquadrata Grozd. et Leb., Ps. pseudoquadrata Man., Ozawainella cf. pararhomboides Man., Hemifusulina concepta Chern., Aljutovella ex gr. novoburasiensis Leon., Al. artificialis (Put.), Al. cf. subaljutovica Saf., Al. elongate (Raus.), Al. skelnevatica (Put.), Schubertella pauciseptata Raus. Подобный комплекс обнаружен в прослоях известняков, расположенных в верхах разреза свиты в скважинах Саратовской области (Тепловская, Гусихинская и Курдюмская площади), но в вышележащих известняках встречены уже каширские фораминиферы и брахиоподы. Д.А. Кухтинов с соавторами предлагают проводить границу между верейским и каширским горизонтами по подошве конгломератовидных известняков, с которых начина-ется новый цикл седиментации. Возможно, имели место обмеление бассейна или некоторый перерыв в осадконакоплении, приходящийся на границу горизонтов.

Подробный анализ расположения границы между верейским и каширским горизонтами в разрезах Саратовского Поволжья проведен в работе [16]. Авторы отмечали присутствие в основании каширских отложений конгломератовидных известняков с микрофауной смешанного (верейско-каширского) типа. Они выделили четыре фациальные зоны: 1) Правобережье, 2) ближнее Заволжье, 3) север Заволжья (пугачевский тип разреза), 4) дальнее Заволжье (рахмановский тип разреза). На севере первого района (Тепловская, Гусихинская площади) наблюдалось сокращение мощностей карбонатных пород в верейском горизонте. К югу (Елшанская площадь) среди терригенных отложений присутствуют прослои органогенно-обломочных известняков, а также разнообразные породы от глинисто-песчанистых известняков до известковистых песчаников и алевролитов с постепенными переходами между ними. Далее на юг (бассейн Иловли) нарастает степень опесчанивания разреза. При движении к востоку сначала происходит замещение терригенно-карбонатной пачки на преимущественно терригенный состав, а затем наблюдается обратная тенденция, т.е. в разрезах рахмановского типа возрастает роль известняков. Однако микрофауна сходна с вышеописанным составом. Эти сведения интерпретируются исследователями как указание на неустойчивое осадконакопление в конце верейского времени, когда возникали многочис-ленные локальные перерывы. Лишь в районе Пугачева (третья зона) они отмечали углубление моря, приходящееся на границу верейского и каширского горизонтов.

Таким образом, необходимость выделения бахметьевской свиты определяется, прежде всего, наличием перерывов седиментации на ее нижней и верхней границах небольших амплитуд, особенностями литологического состава и своеобразной палеонтологической характеристикой, но с присутствием транзитных видов фузулинид. Несмотря на литологическую изменчивость на изученной территории, предлагаемое деление наиболее полно отвечает наблюдаемым фактам. Выделенные пачки отличаются между собой не только литологией, но и составом фораминиферовых комплексов. Однако границы между ними часто являются нечеткими, что обусловлено латеральным замещением одних литологических разновидностей другими и хорошо видно при анализе каротажных диаграмм. Эти пачки предлагается рассматривать в ранге подсвит бахметьевской свиты, что лучше отвечает требованиям «Стратиграфического кодекса». В этом случае они могут быть соотнесены с фораминиферовыми зонами, которые ранее намечались в Поволжье с некоторыми уточнениями. В нижней глинистой подсвите наблюдается комплекс Brunsiella irregularis - Schubertella gracilis, в средней песчано-глинистой подсвите - комплекс Hemifusulina? conceptta-Aljutovella aljutovica и в верхней карбонатно-терригенной подсвите - комплекс Schubertella pauciseptata - Pseudostaffella pseudoquadrata. Очевидно, последующий анализ фактических материалов позволит детализировать расчленение. Во всяком случае, предлагаемое деление горизонта является более дробным, по сравнению с представлением А.С. Мельниковой и др. [2].

В Тормосинской опорной скважине вскрыта толща объединенных верейских и мелекесских отложений мощностью 590 м. Они имеют сходный вещественный состав. В работе [2] приводятся литологическая колонка и палеонтологические сведения (рис. 2). Можно полагать, что типично верейские образования располагаются в интервале 2260-2387 м. Здесь выделяются три литологические пачки (снизу вверх): глинистая (2387-2346 м), глинисто-песчаниковая (23462295 м) и глинисто-алевролитовая (2295-2260 м). Фауна была обнаружена в прослоях следующих известняков (интервал 2270-2276 м): Al. ex gr. aljutovica Raus., Eofusulina triangula (Raus. et Bel.), Profusulinella arta Leon., Pr. rhomboids Lee et Chen., Pseudostaffella subquadrata Grozd. et Leb., Ps. ex gr. pseudoquadrata Man., Ps. gorskyi (Dutk.), Ozawainella facoides Man. Этот список в целом аналогичен приведенному Д.А. Кухтиновым с соавторами. Точно так же разрез разделяется на три части. Подобную биостратиграфическую характеристику верейских отложений по разрезам скважин Верховской площади приводили 


\begin{tabular}{|c|c|c|c|c|c|c|c|c|}
\hline 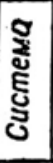 & ธ్ర్ & कू & 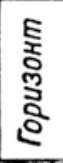 & 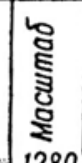 & 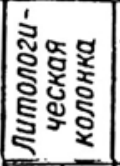 & 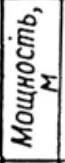 & $\begin{array}{l}\text { Јитологическая } \\
\text { ха ракте ристика }\end{array}$ & $\begin{array}{l}\text { Фаунистическая } \\
\text { характеристика }\end{array}$ \\
\hline \multirow{4}{*}{$\begin{array}{l}a \\
0 \\
2 \\
0 \\
5 \\
0 \\
\infty \\
0 \\
0 .\end{array}$} & \multirow{4}{*}{\begin{tabular}{|l} 
\\
\\
\\
\\
0 \\
$>$ \\
0 \\
0 \\
0 \\
0 \\
0
\end{tabular}} & \multirow{4}{*}{$\begin{array}{l}D \\
> \\
x \\
0 \\
0 \\
0 \\
x \\
0 \\
0 \\
\Sigma\end{array}$} & 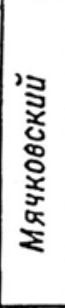 & $\begin{array}{l}1330 \\
1380 \\
1430 \\
1480 \\
1530\end{array}$ & 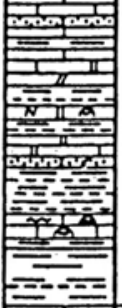 & ָे & 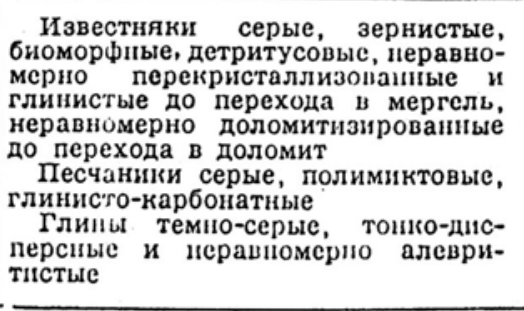 & 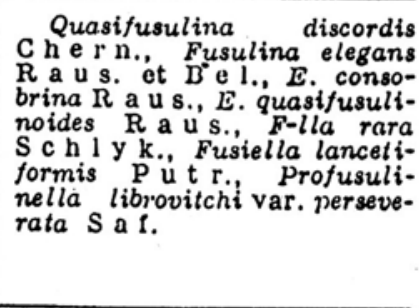 \\
\hline & & & 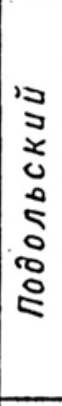 & $\begin{array}{l}1580 \\
1630 \\
1680 \\
1730 \\
1780 \\
1830 \\
1880 \\
1930\end{array}$ & 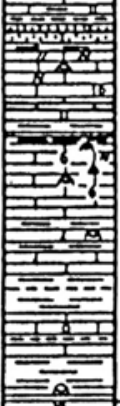 & 을 & 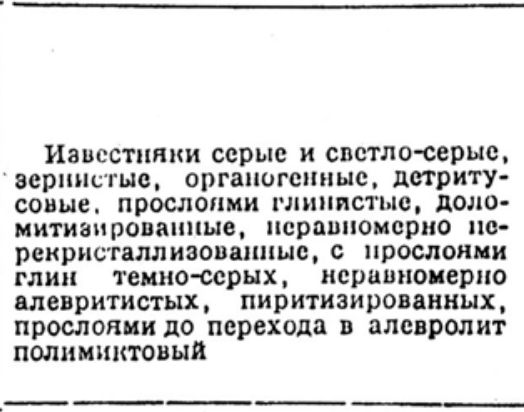 & 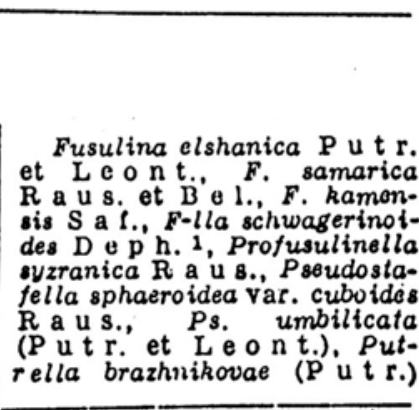 \\
\hline & & & $\begin{array}{l}3 \\
\vdots \\
x \\
0 \\
0 \\
\vdots \\
\exists \\
0 \\
0\end{array}$ & $\begin{array}{l}1980 \\
2030 \\
2080 \\
2130 \\
2180 \\
2230\end{array}$ & 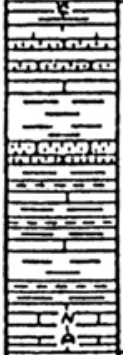 & ঙ্ & 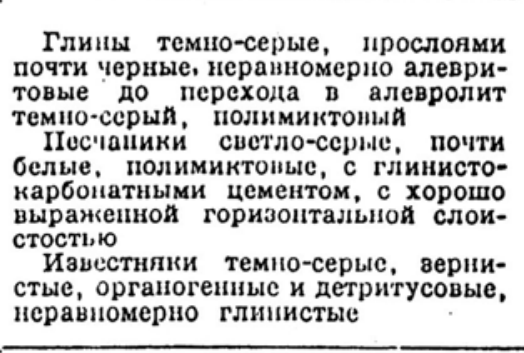 & 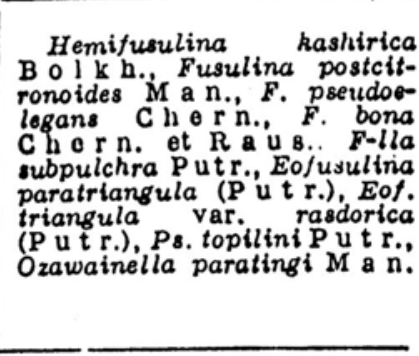 \\
\hline & & & $\begin{array}{l}3 \\
\vdots \\
x \\
0 \\
0 \\
0 \\
0 \\
0 \\
0 \\
\infty\end{array}$ & $\begin{array}{l}2280 \\
2330 \\
2380 \\
2430\end{array}$ & 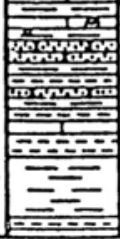 & कृ & $\begin{array}{l}\text { Переслаивание алевролитов, пес- } \\
\text { чаниюов и глин. Алевролиты серые } \\
\text { и темно-ссрые, полимиктовые } \\
\text { Песчаники светло-серые, поли- } \\
\text { миктовые, с глинисто-карбонатным } \\
\text { цементом, с обрывками обуглив- } \\
\text { шихся растительных остатков } \\
\text { Глины темно-ерые, неравномер- } \\
\text { нолевритистые }\end{array}$ & 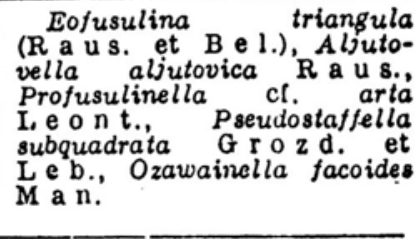 \\
\hline
\end{tabular}

Рис. 2. Геологический разрез среднего карбона Тормосинской опорной скважины [2]

Е.Н. Семихатова [11] и В.Е. Лацкова с соавторами [12] для Саратовского Заволжья. Существенных отличий по составу фузулинид, по сравнению с данными Д.А. Кухтинова с соавторами, не отмечено, что позволяет использовать предлагаемые фораминиферовые зоны, несмотря на присутствие ряда транзитных видов.

В фациальном отношении верейские отложения принадлежат к лагунной и прибрежноморской фациям наступающего морского бассейна, который после некоторого перерыва на границе башкирского и московского веков вновь развивался в Поволжье, а затем регрессировал в конце верейского времени. По сравнению с Подмосковьем, где часто наблюдаются перерывы седиментации между свитами, в Поволжье нижняя и верхняя границы бахметьевской свиты только условно соответствуют перерывам небольшой амплитуды. Внутри свиты падение уровня моря не является пока что достоверно установленным. Подсвиты в Поволжье с некоторой степенью условности можно сопоставлять с подмосковными свитами.

Каширский горизонт $\mathbf{C}_{\mathbf{2}} \mathbf{k s}$ в Подмосковье [8] представлен неоднократным чередованием терригенных и карбонатных пород, которые подразделяются на четыре свиты и фораминиферовые зоны (снизу вверх): цнинскую (зона Priscoidea priscoidea), нарскую (зона Hemifusulina moelleri-Beedeina pseudoelegans), лопаснинскую (зона Moellerites praecolanie) и смедвинскую (зона Hemifusulina vozhgalica). Границы свит совпадают с перерывами в осадконакоплении и в их основаниях в разных разрезах залегают то терригенные породы с обломками кремней, то известняки с обломками подстилающих образований. Перерывы соответствуют выраженным падениям уровня моря. 
В Поволжье четко обособляются три района в едином регионе, охватывающем ВолгоградскоСаратовское Правобережье (с юга на север), в которых каширские отложения имеют различный литологический состав, причем фораминиферовые комплексы не в полной мере совпадают с подмосковными, особенно на юге территории. В первом районе, в Тормосинском прогибе, подробно описанном Н.И. Погребновым с соавторами [17], А.С. Мельникова с соавторами [2] наблюдали увеличенные мощности трех литологических пачек (см. рис. 2): глинисто-известняковой (интервал 2168-2260 м), известняково-терригенной (2020-2168 м) и терригенно-известняковой (19952020 м). Авторы приводили литологическую и палеонтологическую характеристики отложений. Нижняя пачка слагается преимущественно известняками с подчиненными прослоями глин, алевролитов и песчаников, содержащих обугленные растительные остатки и конкреции сидеритов. В редких прослоях известняков установлены фузулиниды Fusiela praecursor var. paraventricosa Raus., Fusulina schellwieni Staff., F. ninensis Put., F. subdistenta Put., F. postcitronoides Man., F. pseudoelegans Chern., Pseudostaffella ozawai (Lee et Chen.), Eofusulina triangula var. rasdorica (Put.), Profusulinella librovichi (Dutk.), Pr. prolibrovichi Raus., появляются первые Petrella gurovi Put. B средней пачке наблюдается чередование глин, алевролитов, песчаников с подчиненными прослоями известняков. Встречены в значительных количествах Eofusulina trianguliformis Put., Eof. rasdorica (Put.), Profusulinella pseudorhomboides (Put.), Pr. parva var. robusta Raus. et Bel., Pr. rhomboids (Lee et Chtn.), Pr. librovichi (Dutk.), oтмечено присутствие верейских видов. В верхней пачке фиксируется переслаивание известняков и глин. Первые породы составляют пять пластов мощностью 4-15 м. Характерен обедненный состав фузулинид. Встречены виды Aljutovella ex gr. subaljutovica Saf., Al. aljutovica Raus., Al. postaljutovica Saf., появляются Dagmarella prima Sol., Fusulinella subpulchra Put., Fusulina meeki (Dunb. et Cond.), отмечено присутствие видов, установленных в нижних пачках. Эти отложения предлагается обособить в чирскую свиту $\mathrm{C}_{2} \mathrm{chr}$ с типовым разрезом по Тормосинской опорной скважине. Наименование стратона дано по одноименной структуре, в пределах которой расположена скважина.

Второй район ограничен Арчединскими поднятиями и прилегающей площадью. Здесь выделяются три литологические пачки: нижняя мергельно-известняковая, средняя известняковопесчано-глинистая и верхняя известняковая [2, 4]. По сравнению с Тормосинским прогибом мощности снижаются, в разрезах возрастает доля карбонатных пород. Нижняя пачка мощностью 30-70 м представлена в основном органогеннообломочными известняками, содержащими примесь глинистого вещества, с прослоями мергелей и известковистых алевритистых глин. Меняется и состав фораминиферовых комплексов. А.С. Мельникова с соавторами приводили список фораминифер: Eofusulina paratriangula Put., Eof. trianguliformis Put., Eof. triangula var. rasdorica (Put.), Fusulina subdistenta Put., F. ex gr. rasdorica (Put.), F. bona Chern.et Raus., F. postcitronoides Man., F. pseudoelegans Chern., Dagmarella prima Sol., Hemifusulina volgensis (Put. et Leon.), H. dutkevichi (Put.), H. aff. communis Raus., H. kashirica Bolk., H. pseudobocki (Put. et Leon.), H. moelleri Raus., H. consubrina Raus., Psedostaffella topilini Put., Ps. pseudoquadrata Man., Ps. gorskyi (Dutk.), Schubertella magna Lee et Chen., Fusulinella subpulchra Put., Ozawainella paratingi Man., Oz. pseudoangulata Man. Авторы считали, что это типично каширская ассоциация. Подробное вертикальное распространение фораминифер по разрезу верховских скважин приводила Е.Н. Семихатова [11]. К указанному списку она добавляла Eof. acuta Grozd. et Leb., Eof. mutabilis Raus., Sch. acuta Raus., Ps. ozawai Lee et Chen., Ps. sphaeroidea (Ehr.). В Николаевской опорной скважине дополнительно отмечалось присутствие Aljutovella cf. postaljutovica Saf., Al. dilucida Saf., Eof. subtissima Put., Profusulinella constans Saf., Pr. timanica Raus. Г.М. Яриков с соавторами [14] отмечали встречаемость верейских форм в низах разреза. Из брахиопод они обнаружили Phrycodothyris asiatica (Chao), Dictyoclostus cf. obraszowiensis Iv., Marginifera cf. borealis Iv., Krotovia cf. karpinskiana (Jan.), Chonetes carboniferus Keys., Canerinella sp., Orthoteta sp., Buxtonia sp.

Средняя пачка представлена переслаивающимися глинами с обилием растительного детрита, разнозернистыми известковистыми песчаниками с растительными остатками, мергелями и органогенно-обломочными глинистыми известняками. Мощность колеблется в пределах 40-50 м с тенденцией увеличения в восточном направлении. В Николаевской опорной скважине она сложена преимущественно темно-серыми глинами. Здесь встречены брахиоподы Meekella aff. venusta (Traut.), Pugnax ex gr. swallowiana (Schum.), Buxtonia aff. mosquensis Iv., Chonetes carboniferus Keys., Orthotetes sp. А.С. Мельникова и др. указывали на присутствие фораминифер Hemifusulina communis Raus., H. borealis Raus., H. acuta Raus., Ozawainella paratingi Man., Pseudostaffella mosquensis Raus., которые наблюдались и в нижней пачке. Примерно такой же состав микрофауны указан Е.Н. Семихатовой для Верховской площади, хотя отмечены и некоторые новые виды.

Верхняя пачка представлена главным образом органогенно-обломочными глинистыми известняками с прослоями мергелей, доломитов и тонкослоистых известковистых глин, мощность которых составляет 80 м на Шляховской площади. Здесь встречены брахиоподы Phricodothyris asiatica (Chao), Choristites cf. teshevi Iv. et Iv., Ch. cf. sowerbyi Fish. var. alata Iv., Chonetes carbon- 
iferus Keys., Athyris sp. [13]. Из фораминифер обнаружены массовые Hemifusulina pseudobocki (Put. et Leon.), H. kashirica Bolk., H. proelengatula Raus., Fusulina bona Chern. et Raus., F. schellwieni Staff., F. apokensis Raus., F. pseudoelegans Chern., F. postcitronoides Man., F. rauserae Chern., F. juncta Chern., Fusulinella subpulchra Put., Fus. subcolaniae Dalm., Fus. praecolaniae Saf., Fus. colaniae Lee et Chen., Putrella gurovi (Put.), P. brazhnikovae (Put.) [2]. В верхах каширского горизонта в Николаевской опорной скважине Г.М. Яриков с коллегами выявили обедненный комплекс несколько иного состава, в котором присутствуют нижнеподольские виды (Fusulinella paraschubertellinoides Raus., Pseudostaffella umbilicata (Put. et Leon.), Ps. syzranica Raus. et Saf., Ps. ivanovi Raus., Fusulina cf. bona Chern. et Raus., Ozawainella tingi (Lee)). B середине пачки установлены типичные каширские виды: Hemifusulina moelleri Raus., $H$. pseudobocki (Put. et Leon.), Fusulinella subcolaniae Dalm., Fus. subcolaniae var plana Reitl., Pseudostaffella topilini (Put.) [14].

Между выделенными литологическими пачками исследователи не указывали следов перерывов в седиментации. Несмотря на некоторые отличия в составе фораминиферовых комплексов, все-таки можно видеть значительную общность ассоциаций. Особенности литологии и палеонтологическая характеристика позволяют рассматривать описанные отложения в качестве нового местного подразделения - верховской свиты $\mathrm{C}_{2} \mathrm{wr}$, разделенной на три подсвиты, coответствующие литологическим пачкам с заключенными в них комплексами фораминифер. Название свиты дано по Верховской структуре на юге Доно-Медведицких дислокаций, где расположены скважины Шляховской, Верховской площадей (см. рис. 1), в которых получены обширные литологические и палеонтологические данные. Е.Н. Семихатовой рекомендовались разрезы по скв. $1 p, 3 p, 16,24$ Верховской разведочной площади без указания интервалов глубин для этого подразделения. С учетом этих сведений свиту можно рассматривать в объеме фораминиферовых зон Ozawainella digitalis-Aljutovella postaljutovica, Hemifusulina communis-H. kashirica-Fusulinella praecolaniae и Hemifusulina moelleri-H. pseudobocki. Такая зональность отличается от принятой для Подмосковья, что объясняется своеобразием условий седиментации каширских отложений на юге Волгоградской области. В качестве парастратотипа можно принять разрез по Николаевской опорной скв. 2 с интервалами глубин для каждой подсвиты (сверху вниз) 2949-3039 м, 3039-3075 м, 3075-3167 м. В фациальном отношении верховская свита характеризует мелководный морской бассейн.

Нижняя граница свиты совпадает, очевидно, с перерывом [10], хотя многие исследователи не приводили каких-либо сведений по этому поводу. Продолжительность его была, вероятно, незначительной, так как в низах каширских отложений отмечаются некоторые верейские виды фораминифер. Они в Саратовской области имеют цнинский возраст, для них характерно смешение разновозрастных фораминифер $[16,18]$. Верхняя граница свиты является не вполне ясной. С одной стороны, в Николаевской опорной скважине отмечается обедненность фауны в верхах известняковой пачки, но одновременно встречаются виды, характерные для подольского горизонта. С другой - эта граница в Подмосковье фиксируется по перерыву в осадконакоплении, совпадающему с падением уровня моря. Более того, M.X. Maxлина с коллегами [8] считают, что с подольского горизонта начинается новый цикл седиментации, продолжающийся до конца дорогомиловского времени. Следовательно, будущие исследования в Нижнем Поволжье должны быть посвящены более подробному изучению взаимоотношений каширского и подольского горизонтов.

Совершенно иной (преимущественно карбонатный) литологический состав каширских отложений наблюдается в Саратовском Правобережье (третий район). Е.И. Чернова [13] изучила их биостратиграфию на Гусихинской, Тепловской, Елшанской и Курдюмской площадях, где выделила три фораминиферовые зоны (снизу вверх): Profusulinella biconiformis - Hemifusulina communis, Aljutovella priscoidea - H. kashirica и H. pseudobocki. В Заволжье В.Е. Лацкова с коллегами [12] выделили другие фораминиферовые зоны (снизу вверх); узкие Ozawainella-Schubertella gracilis var. znensis (мощность 10-20 м), Hemifusulina communis-H. dutkevichi (мощность 60-70 м) и H. pseudobocki-H. kashirica (мощность около 30 м).

М.Н. Соловьева на основе переизучения стратотипов в Подмосковье [19, 20] проанализировала состав фораминифер во многих разрезах каширских отложений на территории Русской платформы и показала необходимость выделения цнинского горизонта в низах каширского яруса. Недавно В.С. Губарева и Г.М. Сунгатуллина [21] вернулись к этому вопросу, так как в современной региональной стратиграфической схеме это подразделение в ранге горизонта отсутствует, но выделяется в ранге свиты [8]. М.Н. Соловьева, по данным В.Е. Лацковой и др., считала, что их самая нижняя зона Ozawainella-Sch. gracilis var. znensis должна относиться к цнинскому горизонту. Он характеризуется максимумом развития профузулинеллово-альютовелловых сообществ, хотя и несет черты преемственности от верейских комплексов. Это происходит по линиям родов Aljutovella и Profusulinella, причем представители первого рода усложняют свое строение (вместо субромбоидальных форм в верейских отложениях пришли веретеновидные, с округленными оборотами, со складчатостью (priscoidea). Появляются Hemifusulina volgensis, развиваются Pr. ovata-Pr. nuratavensis. М.Н. Соловьева приводила следующий характерный состав комплекса: Sch. 
gracilis znensis, Sch. galenae, Oz. digitalis, Pr. prisca timanica, Pr. paratimanica, Pr. nuratavensis, Pr. ovata, Taitzehoella prolibrovichi, T. pseudolibrovichi, Al. parasaratovica, Al. saratovica, Al. priscoidea, Al. znensis, H. dutkevichi, H. volgensis. В собственно каширских отложениях наблюдается иной состав комплекса: Oz. vozhgalica, T. pseudolibrovichi, $H$. kashirica, H. moelleri, H. communis acuta, Beedeina ozawai, B. paraozawai.

По данным В.Е. Лацковой и др., в Пугачевской скв. 10 (интервал 752-784 м) обнаружены Sch. gracilis var. znensis Raus., Sch. acuta Raus, Pseudostaffella ex gr. topilini Put., Profusulinella mutabilis Saf., Ps. biconiformis Kir., Pr. pseudolibrovichi Saf., Pr. praelibrovichi Saf., Pr. ovata Saf., Pr. priscva Depr., Aljutovella aljutovica (Raus.) Al. distorta Leon., Al. conspecta Leon., а также брахиоподы Dictyocloctus aff. obraszoviensis Iv., Productus moelliri Stuck., Krotovia karpinskiana Yan. При этом, судя по каротажной диаграмме, приводимой в работе [9], граница между цнинскими и собственно каширскими отложениями характеризуется четким минимумом на кривой электросопротивления и максимумом на кривой ПС, которые совпадают с пачкой известковистых глин и песчаников. Подобное поведение каротажных кривых, сопряженных с изменением состава фораминиферовых комплексов, отмечается в работе [16], где авторы протрассировали границу от Правобережья до дальнего Заволжья Саратовской области. Наконец, Ю.М. Мартынов и И.А. Чернова [18] определенно выделяют цнинские отложения в разрезах ряда скважин на территории Саратовской области (табл. 1).

Таблииа 1

Скважины в Саратовском Поволжье, вскрывшие цнинские отложения [18]

\begin{tabular}{|l|c||l|c|}
\hline $\begin{array}{c}\text { Разведочная площадь. } \\
\text { Номера скважин }\end{array}$ & $\begin{array}{c}\text { Интервалы глубин, м } \\
\text { (мощность, м) }\end{array}$ & $\begin{array}{c}\text { Разведочная площадь. } \\
\text { Номера скважин }\end{array}$ & $\begin{array}{c}\text { Интервалы глубин, м. } \\
\text { (мощность, м) }\end{array}$ \\
\hline Пугачёвская 10 & $752-784(32)$ & Советская 2 & $1220-1252(32)$ \\
\hline Песковатская 2 & $775-814(39)$ & Сусловская 1 & $887-916(29)$ \\
\hline Багаевская 1 & $1138-1173(35)$ & Александровская 28 & $1141-1183(42)$ \\
\hline Елшанская 2 с & $281-320(39)$ & Горючкинская 11/ 8 бис & $1246-1285(39)$ \\
\hline Квасниковская 13 & $401-439(38)$ & Красноармейская 3 & $1520-1549(29)$ \\
\hline Генеральская 6 & $721,5-757(35,5)$ & Иловлинская 17 & $1088,5-1126(37,5)$ \\
\hline Степновская 4 & $1123-1152(29)$ & Каменская 4 & $1808-1846(38)$ \\
\hline
\end{tabular}

В литологическом составе преобладают глинисто-карбонатные породы. В их основании прослеживается маломощная пачка глинистых известняков и известковистых глин, по подошве которых проводится граница между цнинскими и верейскими отложениями, что подтверждается палеонтологическими сведениями. Перекрывающие каширские образования представлены карбонатными породами, более чистыми от терригенных примесей. Это служит дополнительным признаком для расчленения стратонов, что хорошо видно в разрезе Пугаческой скважины [9]. Мощность цнинских отложений колеблется в пределах $25-45 \mathrm{M}$.

Изложенные свойства цнинских образований дают основание для их обособления в собтвенный стратон - квасниковскую свиту $\mathrm{C}_{2} \mathrm{kv}$, начинающую разрез каширского горизонта в Саратовской области. Название дается по одноименой разведочной площади, в пределах которой в скв. 13 вскрыт наиболее мощный разрез. Очевидно, они характеризуют переходную зону осадконакопления между югом Волгоградской области и северными районами Поволжья. Здесь, видимо, отмечается углубление бассейна седиментации при одновременом снижении интенсивности привноса терригенного материала, который почти исчезает из разреза в более позднее каширское время. Свите присущ фораминиферовый комплекс
Ozawainella digitalis - Aljutovella priscoides - Schubertella gracilis znensis.

Существенно карбонатная часть каширских отложений описана Л.Н. Ивановой и Д.А. Кухтиновым [9], которые в качестве стратотипа выделенной ими ириновской свиты $\mathrm{C}_{2}$ ir приняли разрез по Пугачевской опорной скв. 10 (интервал 629-752 м) с изображением каротажной диаграммы. Заметим, что нижняя часть разреза до глубины 752 м ошибочно отнесена ими к ириновской свите.

По литологическим особенностям разрез свиты делится на три части. Низы (интервал 720-752 м) сложены буроватыми неравномерно глинистыми известняками. Е.И. Чернова [13] отмечала присутствие глинистых и доломитизированных разностей в Тепловском и Елшанском районах. Комплекс фораминифер, по данным Л.Н. Ивановой и Д.А. Кухтинова, представлен единичными Aljutovella postaljutovica Saf., частыми Profusulinella eolibrovichi Saf., Pr. prolibrovichi Raus., Pr. pseudolibrovichi atelica Raus., Pr. biconiformis Kir., Pr. prisca timanica Kir., Pr. prisca (Depr.), Pseudostaffella antiqua (Dutk.), Ps. gorskyi (Dutk.), Ps. umbilicata (Put. et Leon.), Eofusulina triangulata (Raus. et Bel.). Встречаются также брахиоподы Neochonetes carboniferus (Keys.), Choristites priscus Eich. Е.И. Чернова дополнительно определила из фораминифер Pr. polasnensis Saf., 
Schubertella obscura Lee et Chen., Sch. galinae Saf., Sch. acuta Raus., Ps. composita Grozd. et Leb., а также указала на присутствие водорослей Beresella. Целесообразно такой состав следует относить к зоне Profusulinella prolibrovichi - Pr. biconiformis.

В средней части разреза (интервал 654-720 м) залегают буро-серые органогенные глинистые известняки. Е.И. Чернова отмечала присутствие доломитов и доломитизированных известняков. Точно так же В.Е. Лацкова с соавторами указывали на неоднократную повторяемость определенных типов пород: глинистых, доломитизированных и сравнительно однородных известняков, что свидетельствует о подвижном гидродинамическом режиме на разных участках бассейна. При этом полнота циклитов различна: иногда отсутствуют нижние (глинистые) элементы, порой не наблюдаются верхние (карбонатные) части. На этом уровне встречены фораминиферы Fusulinella schubertellinoides elschanica Raus., Aljutovella priscoidea (Raus.), Al. saratovica (Put. et Leon.), Al. complicata Saf., Profusulinella prisca (Depr.), Pr. pseudolibrovichi Saf., Pr. paratimanica Kir., Pr. eolibrovichi Saf., Hemifusulina bocki Moell., $H$. pseudobocki Put. et Leon., Pseudostaffella timanica Raus., Ps. gorskyi (Dutk.), Ps. conspecta Raus., Ps. umbilicata (Put. et Leon.), Eofusulina paratriangula Put., Schubertella galinae Saf., Sch. gracilis Raus. и брахиоподы Marginifera kashirica Iv., Choristites priscus Eich., Neochonetes carboniferus (Keys.), Dictyoclostus moelleri Stuck., Krotovia karpinskiana Jan. Дополнительно Е.И. Чернова определила Hemifusulina communis var. acuta Raus., H. splendida Saf., Fusulina ex gr. ozawai Raus. et Bel., F. ex gr. punila Thom., Fusulinella aff. subpulchra Put., Profusulinella ovata Raus., Schubertella obscura Lee et Chen. B.Е. Лацкова с соавторами отмечали, что к этой части разреза приурочен расцвет гемифузулин, а также дополнили список видами Schubertella minima Sos., Pseudostaffella ivanovi Raus., Ps. syzranica Raus. и мелкими фораминиферами Haplophragmina kashirica Reitl., Textularia ex gr. grandis Reitl., T. composita Reitl. По этому составу ассоциаций фораминифер вмещающие отложения могут быть соотнесены с зоной Hemifusulina communis - Profusulinella librovichi.

Разрез свиты заканчивается пелитоморфными, органогенно-обломочными, слабоглинистыми известняками (интервал 629-654 м) с остатками фораминифер Hemifusulina bocki Moell., H. pseudobocki (Put.), H. dutkevichi Put., H. communis Raus., Pseudostaffella ivanovi Raus., Ps. topilini Kir., Ps. umbilicata Put., Ps. sphaeroidea (Eich.), Profusulinella syzranica Raus. et Saf., Pr. polasnensis Raus., Pr. librovichi Dutk., Pr. eolibrovichi Saf., Pr. biconiformis Kir., Pr. ovata Raus., Schubertella gracilis Raus., Sch. acuta Raus., Sch. magna Lee et Chen., брахиопод Choristites ex gr. priscus Eich., Neochonetes carboniferus (Keys.), многочисленных и разнообразных водорослей (Ungdarella,
Beresella). B.Е. Лацкова с соавторами считали комплекс обедненным и представленным теми же видами, которые встречаются в средней части. По данным Е.И. Черновой, в верхах пачки отмечается большая встречаемость видов H. pseudobocki, Ps. umbilicata, Ps. sphaeroidea, Ps. topilini, Pr. librovichi, Pr. ovata. По данному составу фораминифер верхнюю пачку следует относить, очевидно, к зоне Hemifusulina pseudobocki.

Нижняя граница свиты определяется по смене квасниковских карбонатно-терригенных пород на карбонатные образования, причем в основании залегают глинистые известняки, свидетельствующие о вероятном обмелении или перерыве. Верхняя граница проводится по кровле серых глинистых известняков с массовыми брахиоподами Neochonetes carboniferus (Keys.) и фораминифер Hemifusulina, а также по подошве органогенных известняков с подольскими фораминиферами рода Putrella.

Имеющиеся палеонтологические данные [9, $12,13]$ и сходство литологического состава пород в ближнем Заволжье и на Правобережье позволяют относить ириновскую свиту к каширскому горизонту. Выделенные литологические пачки лучше рассматривать в качестве подсвит, отражающих пространственные и временные изменения обстановок осадконакопления на различных участках рассматриваемой территории.

Подольский горизонт $\mathbf{C}_{2}$ pd в стратотипической местности (Подмосковье) представлен главным образом карбонатными породами. На основании детального изучения разрезов с использованием литологического, микрофаунистического и циклостратиграфического методов они подразделены на три свиты (снизу вверх): васькинскую, улитинскую и щуровскую, верх-ние и нижние границы которых приходятся на перерывы в осадконакоплении. Для них приводится состав фораминиферовых [8], конодонтовых [6, 8], мшанковых [7] и брахиоподовых [5] комплексов.

В Поволжье подольские образования распространены повсеместно. Они отсутствуют лишь в районе Хоперской моноклинали. По данным А.С. Мельниковой и др. [2], мощности варьируют в пределах 120-200 м с ростом величин по направлению к Приволжской моноклинали. В общем виде по литологическим признакам авторы [2] отметили присутствие терригенных пород в низах разреза и преобладание известняков и доломитов в его верхах с сокращением доли первых к востоку и северу.

На юге (Тормосинская скв. 1, рис. 2,) наблюдаются иной литологический состав и существенно большие величины мощностей. А.С. Мельникова с соавторами разделили разрез общей мощностью 390 м (интервалы глубин 1540-1930 м) на десять пачек (снизу вверх): 1) глинистую (18 м), 2) известняково-глинистую (60 м), 3) глинисто-алевритовую (10 м), 4) известняковую (15 м), 5) алевролитово-глинистую (32 м), 6) из- 
вестняковую (120 м), 7) известняково-глинистую $(21 \mathrm{M}), 8)$ известняковую $(68 \mathrm{M}), 9)$ алевритопесчаную (32 м), 10) известняковую (14 м). В целом преобладают известковистые глины, содержащие растительные остатки. Известняки микрозернистые органогенно-обломочные, редко отмечаются доломитизированные разновидности. Эти пачки можно объединить в пять циклитов, каждый из которых начинается терригенными породами и заканчивается известняками. Они имеют меняющиеся мощности: I-78 м (пачки 1 и 2); II-25 м (пачки 3 и 4); III-152 м (пачки 5 и 6); IV-89 м (пачки 7 и 8); V-46 м (пачки 9 и 10). В них в низах разреза определены фузулиниды Fusulina pseudoelegans Raus. et Bel., F. bona Chern. et Raus., Putrella gurovi Put., P. cf. donetziana (Lee), P. cf. brashnikovae (Put.), Profusulinella cf. librovichi (Dutk.). Выше в прослоях известняков установлены виды, характерные для подольского горизонта Приволжской моноклинали, дополнительно определены частые псевдоштаффуллы Pseudostaffella imbilicata Put. et Leon., Ps. syzranica Raus., Ps. sphaeroidea var. cuboides Raus., Ps. larinovae Raus. et Saf. Редкая встречаемость микрофауны не позволяет выделять фораминиферовые зоны для каждой литологической пачки. Учитывая преимущественно терригенный состав подольских отложений, развитых на юге Волгоградской области, целесообразно обособить их в самостоятельный местный стратон-аксеновскую свиту $\mathrm{C}_{2}$ ак по названию пос. Верхнеаксеновский, находящегося вблизи Тормосинской скважины. Разрез по ней в указанных интервалах глубин принимается в качестве стратотипического с описанной общей палеонтологической характеристикой. Ареал свиты ограничен районом Донской Луки.

Наиболее полно охарактеризован карбонатный разрез, вскрытый Николаевской опорной скв. 2 (интервал 2792-2949 м), расположенной на левом берегу Волги вблизи г. Камышина [14] (рис. 3). Его предлагается принять в качестве стратотипического для нового местного подразделения - терновской свиты $\mathrm{C}_{2} \operatorname{tr}$. Название дано по населенному пункту Терновка Волгоградской области, неподалеку от которого была пробурена скважина.

Г.М. Яриков с соавторами [14] расчленяли этот разрез на пять пачек. Нижняя известняковая пачка (49 м) сложена темно-серыми слабо доломитизированными глинистыми известняками с редкими прослоями (1-2 м) темно-серых алевритистых глин. В низах ее обнаружены остатки фораминифер каширского и подольского возраста-Hemifusulina paraelliptica Raus., H. communis Raus., H. communis var. acuta Raus., H. nataliae Raus., H. firma Raus., Profusulinella prolibrovichi Saf., Pr. pseudolibrovichi Saf., Pseudostaffella syzranica Raus. et Saf., Ps. larionovae Raus. et Saf., Ps. ozawai var. compacta Man., Ps. umbilicata (Put. et Leon.), Ozawainella pseudo-rhomboides Raus., Oz. paratingi Man., Oz. tingi (Lee), Fusulina bona

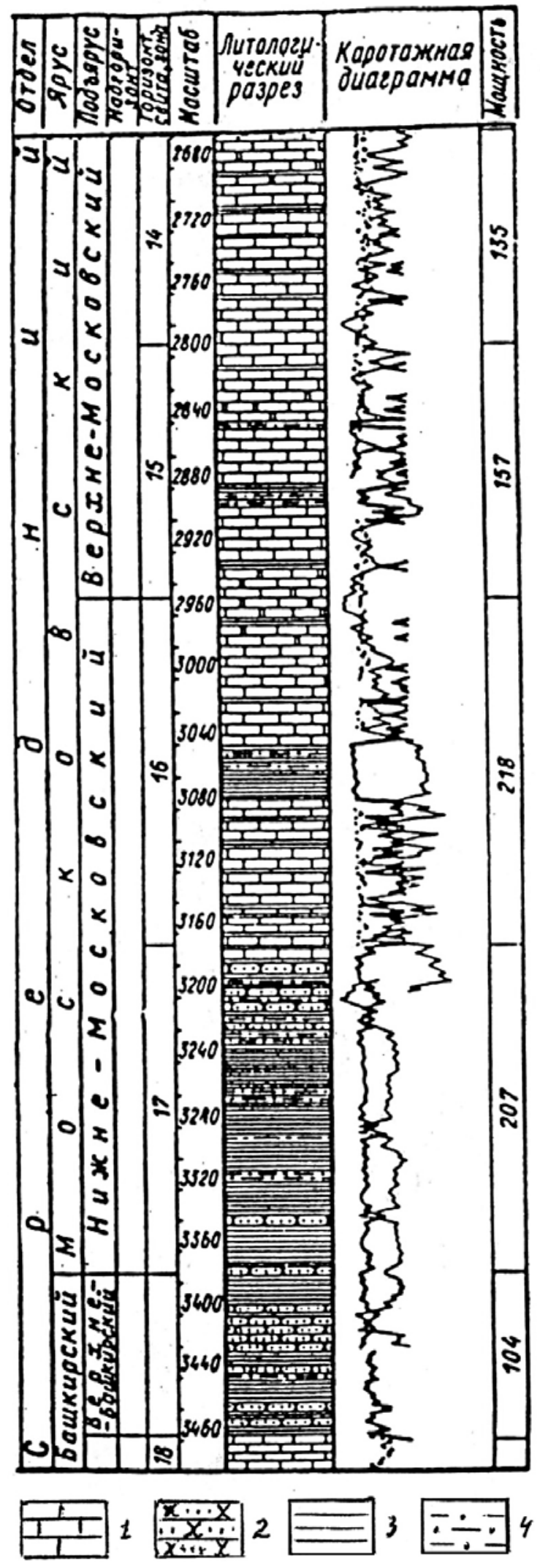

Рис. 3. Геологический разрез среднего карбона Николаевской опорной скважины [14]: 1 - известняки; 2 - песчаники; 3 - глины; 4 - алевролиты; горизонты: 14 -мячковский; 15 - подольский; 16 - каширский; 17 - верейский 
Chern. et Raus., Putrella eicharevi Put. В меньшем количестве встречены типичные подольские виды Fusulina vaskinensis Raus., F. dundari Sosn., Fusulinella paracolaniae Raus., Fus. colaniae Lee et Chen, Fus. borealis (Raus.), Oz. kurochovensis Man. Обнаружены также брахиоподы Krotovia cf. carpinskiana (Jan.), Dictyoclostus ex gr. moelleri (Stuck.), Chonetes carboniferus Keys., Orthotetes cf. regularis (Waag.), Choristites teshevi Iv. et Iv., Meekella cf. exima (Eichw.).

Вторая алевролитово-глинистая пачка с прослоями песчаников (22 м) принята в качестве маркирующего репера в разрезах ВолгоградскоСаратовского Поволжья. Органические остатки в ней не обнаружены. Третья известняковая пачка (34 м) сложена органогенно-обломочными перекристаллизованными, в различной степени глинистыми и доломитизированными известняками серой окраски с редкими прослоями доломитов, содержащими остатки немногочисленных фораминифер Fusulina vaskinensis Raus., F. timanica Raus., F. schelwieni Staff., Fusulinella rasdorica Sem., Putrella licharevi Put., Profusulinella pseudolibrovichi Saf., Ozawainella paratingi Man., Hemifusulina moelleri Raus. и брахиопод Chonetes carboniferus Keys., Krotovia carpinskiana (Jan.). К четвертой маломощной пачке (3 м) отнесены темно-серые известковистые, алевритистые глины с частыми фрагментами колоний мшанок и обломками раковин брахиопод. Верхняя, пятая, пачка (49 м) сложена серыми слабо доломитизированными и неравномерно глинистыми, часто перекристаллизованными и пористыми органогенными известняками, содержащими редкие прослои доломитов. В породах встречен характерный комплекс фораминифер Fusulina kamensis Saf., F. cf. aspera Chern., F. rauserae Chern., F. cf. juncta Chern., F. cf. vaskinensis Raus., F. cf. distenta Roth. et Skin., Fusulinella schwagerinoides var. ovalis Reit., Fus. cf. colaniae Raus., Fus. rasdorica Sem., Fus. decurta Reit., Fus. cf. praebocki Raus., Fus. vozhgalensis var. devexa Raus., Fus. ascherinensis Sem., Fus. schwagerinoides Dep., Profusulinella cf. pseudolibrovichi Saf., Pseudostaffella umbilicata (Put. et Leon.), Ps. cf. syzranica Raus. et Saf., Ps. sphaeroidea Ehr., Hemifusulina cf. bocki Raus. и брахиоподы Chonetes carboniferus Keys., Concrinella $\mathrm{sp}$.

А.С. Мельникова с соавторами [2] для большей части территории Волгоградской области, Е.Н. Семихатова [11] для юга Доно-Медведицких дислокаций, В.Е. Лацкова с соавторами [12] для Саратовского Заволжья и Е.И. Чернова [13] для Саратовского Правобережья приводили обширные данные по составу комплексов фораминифер подольского горизонта. Е.И. Чернова предложила зональное деление, сходное с подмосковным.

По данным Е.И. Черновой, нижняя зона $P u$ trella brazhnikovae характеризуется комплексом, в котором, помимо вида-индекса, часто встречаются Hemifusulina splendida var. globulosa Saf., Fusulina dunbari Sos., F. meeki (Dunb. et Cond.), F. ozawai Raus. et Bel., F. consobrina Saf., F. pumila var. septata Put., Fusulinella pseudobocki Lee et Chen., Profusulinella pseudolibrovichi Saf., Pr. praelibrovichi Saf., Pr. librovichi (Dutk.), Ozawainella mosquensis Raus., Oz. paratingi Man., Oz. angulata (Col.), Oz. pseudoangulata Put., Eofusulina trianguliformis (Put.), Schubertella donetzica Put., Sch. obscura var. compressa Raus., Fusiella pulchella Saf. Можно предположить, что к этой зоне относятся первые литологические пачки, описанные Г.М. Яриковым и А.С. Мельниковой с соавторами.

Следующая зона Fusulinella colaniae (по Е.И. Черновой) выделена по комплексу, в составе которого определены Fusulinella colaniae Lee et Chen., Fus. paracolaniae Saf., Fus. vozhgalensis Saf., Fus. praecolaniae Saf., Pseudostaffella ozawai Lee et Chen., Fusulina adelpha Saf., Fusulina rauserae Chern., F. ozawai Raus. et Bel., F. juncta Chern., F. timanica Raus., F. schellwieni Staff., F. vaskinensis Raus., Fusiella pulchella Saf., Fusiella typica Lee et Chen., Hemifusulina bocki Moell., H. bocki var. fusiformis Brazh., H. splendida var. globulosa Saf. K зоне следует относить вторую и третью пачки, записанные Г.М. Яриковым и др. и пачку перекристаллизованных известняков, изученную А.С. Мельниковой и др.

Верхняя зона Fusulina aspera Е.И. Черновой отлична от подмосковной Fusulinella chernovi. Комплекс представлен видами Fusulina aspera Chern., F. lucida Chern., F. rauserae Chern., F. elegans Raus. et Bel., F. ozawai Raus. et Bel., Pseudostaffella ozawai Lee et Chen., Ps. umbilicata Put., Ps. sphaeroidea (Ehr.), Fusiella typica Lee et Chen. Е.И. Чернова отмечала обедненность состава в верхах зоны. Вероятно, этой зоне должны соответствовать четвертая и пятая пачки, изученные Г.М. Яриковым и др. и доломитово-известняковая пачка, описанная А.С. Мельниковой и др.

По поводу характера контактов с ниже- и вышележащими горизонтами в литературе приводится мало сведений. Обычно нижняя граница проводится по кровле глинистых известняков, содержащих массовые раковины брахиопод Neochonetes carboniferus (Keys.) и фораминифер Hemifusulina, и по подошве светлоокрашенных органогенных известняков с типичными видами рода Putrella подольского возраста. Однако эти критерии не очень надежны, так как фоссилии встречаются в довольно широком интервале. В.Е. Лацкова с соавторами [12] рекомендовали проводить границу по появлению Putrella brazhnikovae Put. и в случае частой встречаемости Fusulinella colaniae Lee et Chen., но указывали на вероятный диапазон границы в пределах 20 м. В разрезах скважин, расположенных вблизи Донской Луки, Е.Н. Семихатова [11] отмечала редкую гальку в песках, залегающих в основании темно-серых глинистых известняков, содержащих типичную подольскую фауну. Эти наблюдения позволяют предполагать размывной характер 
нижней границы терновской свиты, о чем свидетельствует также частое присутствие глин, иногда песчаников и глинистых известняков, залегающих в основании.

Верхняя граница подольского горизонта в Поволжье является условной и обычно проводится среди известняков. Она совпадает с отсутствием или обеднением фауны в кровле пород и с появлением мячковских фораминифер в вышележащих отложениях. Кроме фаунистических особенностей, Е.Н. Семихатова указывала на присутствие гальки в песках, залегающих в подошве детритовых известняков мячковского горизонта. Такая же картина отмечалась Г.М. Яриковым с соавторами по Николаевской скважине, принятой в качестве стратотипа для терновской свиты.

Внутри нее границы между пачками определяются литологическими особенностями и составом фораминиферовых комплексов. Но имеющиеся данные показывают, что с юга на север наблюдается смещение терригенных пород вверх по разрезу. Аналогичное поведение свойственно и пачке перекристаллизованных известняков. Тем не менее общая устойчивость смены литологии пород на всей территории Волгоградско-Саратовского Поволжья (к северу от Донской Луки) позволяет рекомендовать описанные пачки в качестве подсвит, которые совпадают по объему с выделенными фораминиферовыми зонами. По литологическим и палеонтологическим особенностям терновскую свиту можно отнести к прибрежно-морской и мелководной фациям, формировавшимся в условиях пульсационной трансгрессии морского бассейна. При этом площадь Донской Луки принадлежит к его периферии. В пользу такой трактовки свидетельствует цикличность разреза. Выделенные подсвиты имеют двучленное строение. Они состоят из нижней глинистой и верхней карбонатной частей.

Мячковский горизонт $\mathbf{C}_{2}$ mc. По комплексу признаков в Подмосковье разрез разделяется на три свиты (снизу вверх): коробчеевскую, домодедовскую и песковскую, которые залегают между собой то согласно (первые две), то с размывом (между второй и третьей). Точно так же отмечается перерыв на границе среднего и верхнего отделов карбона. Для них выделяются комплексы разнообразной фауны [8].

На большей части территории Поволжья в горизонте преобладают карбонатные породы. Однако на юге Волгоградской области наблюдается иной тип разреза. Здесь в Тормосинской скв. 1 (интервал 1247-1540 м) по данным [2, 4] описана значительная доля терригенной составляющей (см. рис. 2). По литологическим особенностям выделяется десять пачек (снизу вверх): 1) алевролитово-глинистая (39 м), 2) известняковая (9 м), 3) глинистая (20 м), 4) известняковая (12 м), 5) алевролитово-песчано-глинистая $(67 \mathrm{M}), 6)$ известняковая $(27 \mathrm{M}), 7)$ известняковоглинисто-алевролитовая $(58 \mathrm{M}), 8)$ известняковая (14 м), 9) глинисто-алевролитовая (14 м),
10) алевролитово-известняковая (25 м) [13]. А.С. Мельникова с соавторами отмечали присутствие пестроокрашенных глин, а в алевролитах - обугленных растительных остатков. Эти данные можно принять за стратотипическое описание новой басакинской свиты $\mathrm{C}_{2}$ bs (название дано по пос. Басакино, расположенному вблизи Тормосинской скважины). Она относится к прибрежноморской фации мячковского горизонта. Ее ареал ограничен самым югом Волгоградской области (до северной излучины Донской Луки).

А.С. Мельникова с коллегами в низах горизонта обнаружили бедную фауну фузулинид, встречающихся и в подольских породах: Fusulina cf. elegans Raus. et Bel., Fusulinella cf. vozhgalensis Saf., Profusulinella biconiformis Kir. В четвертой пачке были определены фораминиферы Quasifusulina discordis Chern., Putrella brazhnikovae (Put.), Fusulinella rara Schlyk., Fus. helenae Raus., Pr. librovichi var. perseverata Saf., а в шестой, седьмой восьмой пачках - Pseudotriticites fallax Chern., Fusiella lancetiformis Put., Fusulina donetziana Put., F. elegans Raus. et Bel., $F$. ex gr. angelinae Put. По такому составу комплекса трудно соспоставить вмещающие породы с фораминиферовыми зонами Подмосковья.

Указанные выше пачки можно объединить в литологические циклиты, в которых сочетаются терригенные (в низах) и карбонатные (в верхах) отложения. В этом случае первая и вторая пачки составят I циклит (мощностью 48 м), в котором установлена бедная фауна; третья и четвертая пачки - II циклит (мощностью 32 м), в котором наблюдаются широко распространенные виды фораминифер; пятая и шестая пачки - III циклит (мощностью 94 м), в породах которого обнаружена более богатая фауна; седьмая и восьмая пачки IV циклит (мощностью 72 м); девятая-одиннадцатая пачки - V циклит (мощностью 39 м), где появляются верхнемячковские виды. Эти циклиты характеризуют пульсационное наступление моря.

На основе результатов микрофаунистических исследований Е.Н. Семихатовой на юге Доно-Медведицких дислокаций можно выделить следующие фораминиферовые зоны (снизу вверх): Fusulina elegans-Fusulinella vozhgalensis, к которой можно отнести I циклит (или подсвиту); Fusulinella bocki, соответствующую II циклиту (подсвите); Putrella brazhnikovae-Fusulinella rara - III циклиту (подсвите); Fusulina donetziana-F. cylindrica - IV циклиту (подсвите); Fusulinella schwagerinoides-Protriticites fallax - V циклиту (подсвите). Такое сопоставление является предварительным. Необходимы более детальные исследования по расчленению мячковских отложений на юге Волгоградской области, чтобы проследить характер осадконакопления и эволюции биоты по мере развития трансгрессии.

Карбонатный тип разреза начинается от северной периферии Арчединских поднятий. По литологическим особенностям А.С. Мельникова с соавторами [2] выделяли пачки стилолитизи- 
рованных известняков, слабо перекристаллизованных известняков, глинистых и трещиноватых известняков. Карбонатные породы представлены серыми сгустковыми и сгустково-детритовыми разновидностями. Отмечались редкие прослои пористых известняков и зелёновато-серых слоистых глин. В первой пачке встречены мячковские фораминиферы - Quasifusulina discordis Chern., Fusulina quasifusulinoides Raus., Putrella brazhnikovae var. korobcheevi Raus., Fusulinella helenae Raus., Fus. bocki Moell., Fus. schwagerinoides (Depr.), Ozawainella cf. angulata (Col.). Во второй пачке обнаружены те же виды фузулинид и впервые появляются Fus. fluxa Raus., Fus. vozhgalensis var. devexa Raus., Fus. vozhgalensis var. molokonensis Raus. В третьей пачке присутствуют многочисленные и разнообразные по составу виды фузулинид. Впервые появляются здесь Fusulina bella Sem., F. cf. nytvica var. callosa Raus., F. parabelocatitvinica Put., Fus. pseudobocki var. ovoides Raus. В четвертой пачке отмечены те же виды.

Г.М. Яриков с соавторами [14] описали мячковские отложения в Николаевской опорной скв. 2 (интервал 2657-2792 м). Разрез они разделили на три пачки. Нижняя из них (интервал 2753-2792 м) сложена органогенно-обломочными известняками с фораминиферами F. samarica Raus. et Bel., F. paradistenta Saf., F. distenta Roth et Skin., характерными для пограничной зоны между подольским и мячковским горизонтами, а также присутствуют типично мячковские формы - Fusulinella bocki Moell., Fus. schwagerinoides (Depr.), Fus. soligalichi var. polasnensis Dalm., Fus. cf. intemerdia Raus., Fus. pseudobocki Lee et Chen. Кроме того, встречены брахиоподы Choristites cf. sowerbyi Fisch., Phricodothyris asiatica (Chao), Chonetes carboniferus Keys., Krotovia cf. carpinskiana (Jan.). Средняя пачка (интервал 26852753 м) представлена органогенно-обломочными, реже водорослевыми известняками, содержащими остатки исключительно мячковских фораминифер - Fus. archedensis Sem., Fus. polasnensis Dalm., Fus. timanica Raus., Fus. cf. mosquensis Raus et Saf., Fus. bocki Moell., Fus. schwagerinoides (Depr.), Fus. podolskensis Raus. Появляются первые Protriticites ovatus Put., Pr.pseudomontiparus Kir. Верхняя пачка (интервал 2657-2685 м) состоит из тонкозернистых доломитизированных и микросгустковых органогенных известняков. Наряду с фузулинеллами из группы Fus. bocki и Fus. schwagerinoides были определены фузулины с удлиненно-ромбической формой раковины - Fusulina donetziana Put., F. cf. belokalitvinica Put., F. cymljanica Put., F. parabelokalitvinica Put., $F$. ex gr. nytvica Raus. В кровле отмечен органогенный известняк с мячковскими фораминиферами.

Автором этой статьи выделяются следующие фораминиферовые зоны (снизу вверх): Fusulinella bocki, включающую первые пачки, по А.С. Мельниковой с соавторами и Г.М. Ярикову с соавторами; Fusulinella podolskensis-Fus. schwagerinoides (вторая и третья пачки, по А.С. Мельниковой с соавторами, средняя пачка, по Г.М. Ярикову с соавторами); Fusulina belokalitvinica-Protriticites ovatus, соответствующую верхним литологическим пачкам, выделенным указанными исследовательскими коллективами.

Границы подольского и мячковского горизонтов и среднего и верхнего карбона обосновывались Е.Н. Семихатовой [11] по биостратиграфическим данным, при этом отмечалось наиболее резкое изменение комплексов на границе ярусов. Она описывала разрезы по ряду скважин на юге Доно-Медведицких дислокаций с приведением обширного списка фораминифер. Следует отметить некоторые ее биостратиграфические выводы: 1) сообщество псевдоштаффел, по сравнению с подольским временем, значительно обеднено; 2) в мячковское время широкое распространение получили фузулинеллы; некоторые из них пришли из подольских слоев (Fus. bocki, Fus. pseudobocki, Fus. helenae, Fus. mosquensis, Fus. rara), другие появились впервые (Fus. soligalichi); 3) виды Fus. bocki и Fus. pseudobocki приобретают все черты типичной мячковской фауны; 4) в верхах горизонта появляется вид Fus. pulchra. Так же широко распространены представители рода Fusulina, сходные с описанными выше. Е.Н. Семихатова считала, что можно выделить три циклита мячковского осадконакопления, которым соответствуют свои сообщества микрофауны: нижний (35-40 м), средний (45-53 м) и верхний (35-40 м).

Е.И. Чернова [13] обобщила фаунистические данные, полученные при изучении керна ряда скважин, пробуренных вблизи Жирновска, и выделила три части, сложенные в основном известняками. Для нижней части характерными видами являются представители группы Fus. bocki-Fusulina distenta Roth et Skin., F. samarica Raus. et Bel., F. elegans Raus. et Bel. Она приводила большой список форм. В середине разреза появляются виды Pseudotriticites mirandus (Grozd.), F. panconensis (Lee) и представители группы Fus. pulchra. Она отмечала присутствие брахиопод Choristites priscus Eich., Ch. priscus var. senilis Iv., Ch. sowerbyi Fisch., Ch. uralicus var. brevicula Iv. et Iv., Brachythyridina strangwaysi Vern., Productus cancriniformis Tschern., Pr. acullatus Mart., кораллов Amplexus rossicus Stuck., Bothrophyllum volgense Stuck. В верхней части обнаружены в массовом количестве фораминиферы F. elegantissima Man., Pseudotriticites fallax Chern. В работе приведен обширный список встреченных видов.

Литологически и палеонтологически изученные мячковские отложения предлагается рассматривать в качестве мельничной свиты $\mathrm{C}_{2} \mathrm{ml}$. Название дано по Мельничному оврагу на правом берегу p. Медведицы вблизи г. Жирновска Волгоградской области, где породы вскрыты в обнажениях и карьерах. Разрезы пробуренных здесь скважин, изученные Е.Н. Черновой [13], можно рассматривать в качестве парастратотипических. За стратотип свиты следует принять разрез по Николаевской опорной скв. 2, где фиксируются нижняя и верхняя границы 
подразделения. Описанные литологические пачки можно рассматривать в качестве подсвит, хотя границы между ними являются не вполне четкими и резкими в относительно однородном известняковом разрезе. Карбонатные породы мельничной свиты характеризуют стадию заметного углубления морского мелководного бассейна, когда в основном отсутствовал привнос терригенного материала. Однако в конце мячковского времени фиксируется перерыв седиментации, свидетельствующий о некотором обмелении моря.

\section{Заключение}

Представленные сведения позволяют произвести сопоставление местных подразделений московского яруса Нижнего Поволжья и Подмосковья между собой и с региональными стратонами (табл. 2). Анализ фактических материалов дает возможность выявить ряд интересных особенностей, касающихся размещения и изменения литологического состава местных подразделений в течение московского века.

Таблица 2

Сопоставление региональных и местных стратиграфических подразделений московского яруса Подмосковья и Нижнего Поволжья

\begin{tabular}{|c|c|c|c|c|c|c|}
\hline \multirow{3}{*}{ 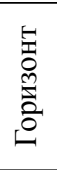 } & \multicolumn{2}{|c|}{ Подмосковье [8] } & \multicolumn{4}{|c|}{ Ни жн е е Поволж ь е } \\
\hline & \multirow[b]{2}{*}{ Свиты } & \multirow{2}{*}{$\begin{array}{l}\text { Фораминиферо- } \\
\text { вые зоны }\end{array}$} & \multicolumn{2}{|c|}{ Северные районы } & \multicolumn{2}{|c|}{ Южные районы } \\
\hline & & & Свиты & $\begin{array}{c}\text { Фораминиферовые } \\
\text { зоны } \\
\end{array}$ & Свиты & $\begin{array}{c}\text { Фораминифе-ровые } \\
\text { зоны }\end{array}$ \\
\hline \multirow{5}{*}{ 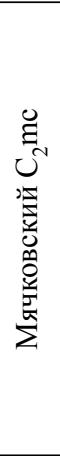 } & \multirow[b]{2}{*}{ Песковская $\mathrm{C}_{2} \mathrm{ps}$} & Protriticitesovatus & \multirow{5}{*}{ 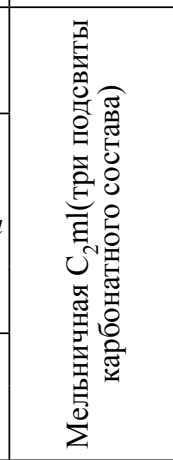 } & $\left|\begin{array}{c}\text { Fusulina belokalitvinica } \\
\text { - Protriticites ovatus }\end{array}\right|$ & \multirow{5}{*}{ 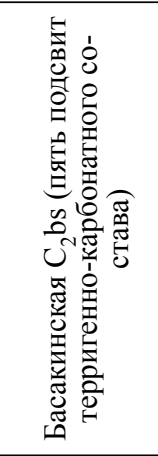 } & $\begin{array}{c}\text { Fusulinella schwageri- } \\
\text { noides - Protriticites } \\
\text { fallax }\end{array}$ \\
\hline & & \multirow[t]{2}{*}{ Fusulinacylindrica } & & \multirow[t]{2}{*}{$\begin{array}{l}\text { Fusulinella podol- } \\
\text { skensis - Fus. Schwa- } \\
\text { gerinoides }\end{array}$} & & $\begin{array}{c}\text { Fusulina donetziana- } \\
\text { F. cylindrica }\end{array}$ \\
\hline & Домодедовская $\mathrm{C}_{2} \mathrm{dm}$ & & & & & \begin{tabular}{|c|} 
Putrella brazhnikovae- \\
Fusulinella rara \\
\end{tabular} \\
\hline & \multirow[b]{2}{*}{ Коробчеевская $\mathrm{C}_{2} \mathrm{~kb}$} & \multirow[b]{2}{*}{ Fusulinellabocki } & & \multirow[b]{2}{*}{ Fusulinella bocki } & & Fusulinella bocki \\
\hline & & & & & & $\begin{array}{l}\text { Fusulina elegans - Fusu- } \\
\text { linella vozhgalensis }\end{array}$ \\
\hline \multirow{3}{*}{ 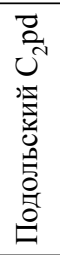 } & Щуровская $\mathrm{C}_{2} \mathrm{sr}$ & $\begin{array}{l}\text { Fusulinella cher- } \\
\text { novi }\end{array}$ & \multirow{3}{*}{ 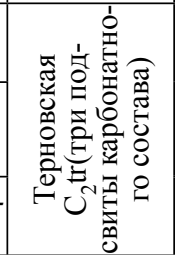 } & $\begin{array}{l}\text { Fusulina aspera }-F \\
\text { lucida }\end{array}$ & \multirow{3}{*}{ 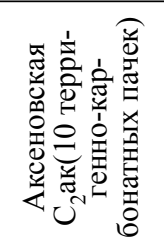 } & \multirow{3}{*}{$\begin{array}{l}\text { Фораминиферовые } \\
\text { зоны не выделяются }\end{array}$} \\
\hline & Улитинская $\mathrm{C}_{2} \mathrm{ul}$ & $\begin{array}{c}\text { Fusulinella cola- } \\
\text { niae - Fusulina } \\
\text { ulitinensis } \\
\end{array}$ & & Fusulinella coraniae & & \\
\hline & Васькинская $\mathrm{C}_{2} \mathrm{vs}$ & \begin{tabular}{|} 
Putrella brazhniko- \\
vae
\end{tabular} & & Putrella brazhnikovae & & \\
\hline \multirow{4}{*}{ 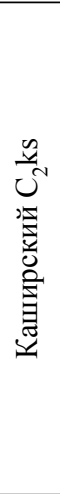 } & Смедвинская $\mathrm{C}_{2} \mathrm{sm}$ & $\begin{array}{l}\text { Hemifusulina vozh- } \\
\text { galica }\end{array}$ & \multirow{3}{*}{ 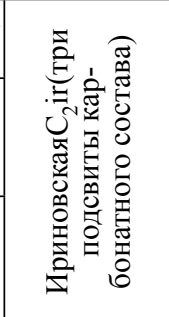 } & $\begin{array}{l}\text { Hemifusulina } \\
\text { pseudobocki }\end{array}$ & \multirow{4}{*}{ 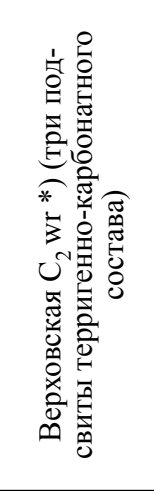 } & $\begin{array}{c}\text { Hemifusulina moelleri- } \\
\text { H. pseudobocki }\end{array}$ \\
\hline & Лопастинская $\mathrm{C}_{2} \mathrm{lp}$ & $\begin{array}{c}\text { Moellerites } \\
\text { praecolaniae }\end{array}$ & & $\begin{array}{c}\text { Hemifusulina com- } \\
\text { munis - Profusulinella } \\
\text { librovichi }\end{array}$ & & $\begin{array}{l}\text { Hemifusulina com- } \\
\text { munis - H. kashirica }\end{array}$ \\
\hline & Нарская $\mathrm{C}_{2} \mathrm{nr}$ & $\begin{array}{c}\text { Hemifusulina } \\
\text { moelleri - Beedei- } \\
\text { na pseudoelegans }\end{array}$ & & $\begin{array}{l}\text { Profusulinella proli- } \\
\text { brovichi -Pr. biconi- } \\
\text { formis }\end{array}$ & & $\begin{array}{l}\text { - Fusulinella praecola- } \\
\text { niae }\end{array}$ \\
\hline & Цнинская $\mathrm{C}_{2} \mathrm{zn}$ & $\begin{array}{l}\text { Priscoidella pris- } \\
\text { coidea }\end{array}$ & 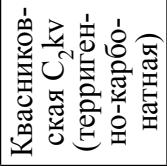 & $\begin{array}{c}\text { Ozawainella digi-talis } \\
\text { - Aljutovella priscoidea } \\
\text { - Schubertella gracilis } \\
\text { zninsis }\end{array}$ & & $\begin{array}{c}\text { Ozawainella digitalis } \\
\text { - Aljutovellapostalju- } \\
\text { tovica }\end{array}$ \\
\hline \multirow{3}{*}{ 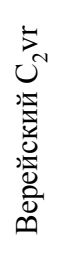 } & Ордынская $\mathrm{C}_{2}$ or & Ovatella arta & \multirow{3}{*}{\multicolumn{2}{|c|}{ Бахметьевская $\mathrm{C}_{2}$ bh (терригенная) }} & \multicolumn{2}{|c|}{$\begin{array}{l}\text { Schubertella pauciseptata - Pseu- } \\
\text { dostaffella pseudoquadrata }\end{array}$} \\
\hline & Скниговская $\mathrm{C}_{2} \mathrm{ks}$ & \multirow{2}{*}{$\begin{array}{l}\text { Aljutovella } \\
\text { aljutovica }\end{array}$} & & & \multicolumn{2}{|c|}{$\begin{array}{l}\text { Hemifusulina (?) concepta - } \\
\text { Aljutovella aljutovica }\end{array}$} \\
\hline & Альютовская $\mathrm{C}_{2} \mathrm{al}$ & & & & Brunziella in & $\begin{array}{l}\text { regularis - Schubertella } \\
\text { gracilis }\end{array}$ \\
\hline
\end{tabular}

* В Тормосинском прогибе вместо верховской выделяется чирская свита $\mathrm{C}_{2} \mathrm{chr}$, разделенная на три подсвиты, соответствующие фораминиферовым зонам (сверху вниз):Al. postaljutovica-Dagmarella prima; Profusulinella pseudorhomboides - Pr. librovichi; Fusulina pseudoelegans - Putrella gurovi. 
1. По сравнению с Подмосковьем, в Поволжье терригенные породы составляют более значительную долю разреза, особенно в низах среднего карбона. При этом начиная с каширского века четко намечаются два района. На юге доминируют алевролитово-глинистые отложения, причем в верхах выделенных свит появляются известняковые пачки. Во втором районе, охватывающем площадь от северной периферии Донской Луки до севера Саратовской области на Правобережье и в Волгоградско-Саратовском Заволжье, в целом преобладает карбонатный тип разреза. Лишь в терновской свите подольского горизонта присутствуют глинистые пачки среди известняков, а в квасниковской свите каширского горизонта отмечаются терригенные разновидности. Бахметьевская свита верейского горизонта и тепловская свита мелекесского горизонта сложены преимущественно чередованием песчаников, алевролитов и глин с прослоями известняков.

2. Если между выделенными свитами с той или иной достоверностью можно признать размывной характер границ, что фиксируется появлением пиков и депрессий на каротажных диаграммах, то между подсвитами этого не наблюдается, в чем и состоит отличие от Подмосковья. Видимо, район от широты Волгограда до северной периферии Саратовской области, включая Заволжье, следует относить к более углубленной части мелководного морского бассейна, удаленного от прилегающей суши, что особенно свойственно Заволжью. В то же время Подмосковье на протяжении почти всего московского века принадлежало к краевой части моря. Поэтому там более четко выражена цикличность осадконакопления с установленными перерывами седиментации.

3. Палеогеографические и литологические особенности свит Поволжья отражаются и в составах фораминиферовых комплексов, которые несколько отличаются от подмосковных сообществ, хотя общие виды, а иногда и целые зональные группы присутствуют в обоих регионах. Несмотря на ряд транзитных форм в изученных подсвитах, все-таки наблюдаются собственные наборы видов микрофауны.

4. Таким образом, в тепловское и бахметьевское время на всей площади ВолгоградскоСаратовского Поволжья существовало мелководное море с присутствием лагун, примыкающее с востока к области размыва [4]. Вследствие этого данным свитам свойствен преимущественно терригенный литологический состав за счет привноса обломочного материала. Подобный характер осадконакопления сохранялся на юге изученной территории на протяжении всего московского века, хотя фиксируются и карбонатные пачки. Сoвершенно иной (карбонатный) тип разреза наблюдается в северном районе, особенно в Заволжье, причем в квасниковской свите (цнинское время) терригенные породы составляют значительную долю, которая к мельничному времени существен- но снижается. Это указывает на постепенную удаленность моря от прилегающей суши, что благоприятствовало формированию карбонатных осадков, в составе которых большую роль играли микрофаунистические остатки. Следовательно, этот район относится к открытому мелководному морскому бассейну.

Очевидно, будущие исследования, аналогичные проведенным в Подмосковье, создадут возможность детализировать установленные закономерности.

Автор данной статьи благодарен А.Ю. Гужикову за обсуждение изложенных фактических материалов и высказанные им критические замечания.

\section{Библиографический список}

1. Кагарманов A.X. Вопросы совершенствования зонального деления каменноугольной системы России // Зональные подразделения карбона общей стратиграфической шкалы России: Материалы Всерос. совещания. Уфа, 2000. C. 3-5.

2. Мельникова А.С., Гогина Е.А., Никитина Г.П. и др. Стратиграфия и литология каменноугольных отложений Волгоградской области // Тр. / Волгоград. НИИПГ. 1962. Вып. 1. С. 39-90.

3. Раузер-Черноусова Д.М., Хачатрян Р.О., Яриков Г.М. Каменноугольная система // Геология СССР. Т. 11. Поволжье и Прикамье. Ч. І. Геологическое описание. М., 1967. C. 226-231.

4. Редичкин Н.А., Яриков Г.М. Каменноугольная система // Там же. Т. 46. Ростовская, Волгоградская, Астраханская области и Калмыцкая АССР. Геологическое описание. M., 1970. C. 111-183.

5. Лазарев С.С. Брахиоподовые зоны московского и касимовского ярусов в стратотипическом районе (Подмосковье) // Зональные подразделения карбона общей стратиграфической шкалы России: Материалы Всерос. совещания. Уфа, 2000. С. 65-66.

6. Алексеев А.С., Горева Н.В. Конодонтовая шкала московского, касимовского и гжельского ярусов // Там же. C. 7-8.

7. Горюнова Р.В. Комплексы мшанок из верейскокревякинского горизонтов карбона Подмосковья // Там же. С. 32-33.

8. Махлина М.Х., Алексеев А.С.. Горева Н.В., Исакова Т.Н. Ритмо- и биостратиграфия карбона Московской синеклизы // Изв. вузов. Геология и разведка. 2001. № 5. C. $42-58$.

9. Иванова Л.Н., Кухтинов Д.А. Ириновская свита - новое подразделение местной шкалы среднего карбона Нижнего и Среднего Поволжья // Недра Поволжья и Прикаспия. 1999. Вып. 19. С. 20-22.

10. Кухтинов Д.А., Серебрякова И.А., Иванова Л.Н., Кухтинова Л.В. Стратиграфия терригенных отложений среднего карбона юго-востока Русской платформы // Там же. 1996. Вып. 11. С. 35-40.

11. Семихатова Е.Н. Значение фораминифер в изучении среднекаменноугольных отложений области Доно- 
Медведицких дислокаций // Региональная стратиграфия CCCP. M., 1961. T. 5. C. 297-358.

12. Лацкова В.Е., Орлова И.Н., Чернова Е.И., РаузерЧерноусова Д.М. Стратиграфия среднекаменноугольных отложений Саратовского Заволжья // Региональная стратиграфия СССР. М., 1961. Т. 5. С. 287-296.

13. Чернова Е.И. Биостратиграфия (по фораминиферам) среднекаменноугольных отложений Саратовского Правобережья // Там же. С. 261-286.

14. Яриков Г.М., Урусов А.В., Золотухина Г.П. и др. Литолого-стратиграфический разрез Николаевской опорной скважины № 2 (предварительные данные) // Тр. / Волгоград. НИИПГ. 1964. Вып. 3. С. 93-111.

15. Стратиграфический кодекс. 2-е изд., доп. СПб., 1992. $120 \mathrm{c}$.

16. Бандорина Э.Е., Королева Н.П., Панькин М.Н. О границе верейского и каширского горизонтов Саратовского Поволжья // Тр. / НВ НИИГГ. 1969. Вып. 9. С. 130-138.
17. Погребнов Н.И., Потапов И.И., Смирнов Б.В. Тектоника // Геология СССР. Т. 46. Ростовская, Волгоградская, Астраханская области и Калмыцкая АССР. Геологическое описание. М., 1970. С. 515-577.

18. Мартынов Ю.М., Чернова И.А. Выделение цнинских отложений в разрезах московского яруса на территории Саратовского Поволжья // Недра Поволжья и Прикаспия. 1995. Вып. 9. С. 26-27.

19. Соловьева М.Н. Зональная фузулинидовая шкала московского яруса по материалам переизучения стратотипов // Вопр. микропалеонтологии. 1986. Вып. 28. C. 3-23.

20. Соловьева М.Н. Коррекция зональных фораминиферовых шкал московского яруса СССР // Там же. 1987. Вып. 29. С. 3-19.

21. Губарева В.С., Сунгатуллина Г.М. К вопросу о выделении цнинского горизонта московского яруса (средний карбон) Восточно-Европейской платформы // Бюл. МОИП. Отд-ние. геол. 2006. Т. 81, вып. 3. С. 50-55. 